\title{
Influence of Subcontractor Risk Management on Quality Performance of Building Construction Projects in Ghana
}

\author{
"Emmanuel Adinyira, Kofi Agyekum, James Cofie Danku, \\ Prince Addison and Augustine Senanu Kukah
}

First submission: 25 February 2020; Accepted: 30 May 2020; Published: 15 December 2020

To cite this article: Emmanuel Adinyira, Kofi Agyekum, James Cofie Danku, Prince Addison and Augustine Senanu Kukah (2020). Influence of subcontractor risk management on quality performance of building construction projects in Ghana. Journal of Construction in Developing Countries, 25(2): 175-197. https://doi.org/10.21315/jcdc2020.25.2.7.

To link to this article: https://doi.org/10.21315/jcdc2020.25.2.7

\begin{abstract}
This study intended to examine the influence subcontractor risk management has on the quality performance of building construction projects. Using a quantitative research method, five hypothesised constructs were tested. The views of 139 Heads of Works for Metropolitan, Municipal and District Assemblies (MMDAs) in Ghana were elicited using a structured questionnaire. A confirmatory factor analysis (CFA) based on structural equation model (SEM) was adopted in analysing the data obtained. The findings suggest that the management of four (financial risks, resource risks, technical risks and managerial risks) out of the five categories of risks positively influenced the quality performance of building construction projects. Relationship risks showed no significant influence on construction quality performance. The study showed quantitatively the effects of sub-contractor risks on quality performance. It provides a vivid relationship between the concept of sub-contracting and quality performance. Therefore, failure to properly manage risks sourced from sub-contractors on a building construction project will have a major adverse consequence on the quality performance of the project. This study further advances efforts at understanding the link between sub-contractor management and project performance with a particular focus on the management of risks emanating from the use of subcontractors on building projects.
\end{abstract}

Keywords: Influence, Building construction projects, Sub-contractor, Quality performance, Risk management

\section{INTRODUCTION}

The building construction industry is known to be a hub of traders from different specialisations. Lew et al. (2018) indicated that the construction industry is unique because of the size and complexity of the projects undertaken, and its nature of "one-time off project" working environment. Because of the dynamic nature of the industry, which requires the solicitation of innovative technologies and the acquisition of modern techniques to enable products to be delivered, it has become necessary for sub-contractors to be hired (El-Kholy, 2019; Lew et al., 2018). A sub-contractor is "a construction company or an individual that contracts with the main contractor to undertake specific tasks on a project as part of the overall contract and may supply labourers, materials, equipment, tools and designs" (El-Kholy, 2019). Samuel (2009) indicated that sub-contractors enter contracts to execute portions or parts of contracts. According to Mbachu (2008),

Department of Construction Technology and Management, Kwame Nkrumah University of Science and Technology, GHANA

*Corresponding author: eadinyira.cap@knust.edu.gh 
sub-contractors may be categorised into three types to include the following: (1) those that specialise in specific trades like paintwork and brickwork (trade subcontractors), (2) those that carry out specialised services like electrical, plumbing and insulation (specialist subcontractors), and (3) those that provide only labour services (labour-only-subcontractors). In the view of Lew et al. (2018), sub-contractors are only recognised as specialists in the implementation of particular works. Subcontracting in the construction industry has gained momentum and it is now widely practiced (Polat, 2016). The benefits of sub-contracting are very evident in the literature. Sub-contractors normally perform as proxies of the production system. Among others, they reduce the overhead cost of the construction project; they ensure the quality of the specialist job and help minimise the financial burden of general contractors (El-Kholy, 2019; Lew et al., 2018; Choudhry et al., 2012).

Polat (2016) reported that over the years the percentage of subcontracted projects in the construction industry has increased. Studies have shown that in a typical construction setting, subcontracting may contribute to between $50 \%$ and $90 \%$ and can even reach as high as $90 \%$ of total project value (Lew et al., 2018; El Mashaleh, 2009; Wang, 2000). Notwithstanding the benefits associated with subcontracting, Lew et al. (2018: 836) cautioned that "extensive subcontracting activities pose risks to general contractors, clients, and their project management teams". Lew et al. (2018) further indicated that the problem is so because of the difficulties such stakeholders encounter in managing such sizeable, varied and fragmented groups of subcontractors. Other studies have also pointed out other risks associated with subcontracting in the construction industry to include: failure in message delivery between parties during the construction stage (Piasny and Paslawski, 2015), delay in completion date (Chiang, 2009) and safety of on-site workers (Awwad, El-Souki and Jabbour, 2016).

In Ghana, it has been shown that in a typical building construction process, subcontracting works constitute about $40 \%$ of the entire process (Kadan, 2016). Looking at this percentage, it would not be a mere exaggeration to conclude that the Ghanaian building industry would face major threats if risks associated with extensive subcontracting are not specifically addressed. This is because the performance and excellence of the subcontractor's project team affect the project outcome concerning quality and timely delivery which is a key determinant of a project's economic performance (Joshi and Lambert, 2011). Ng, Skitmore and Chung (2003) had earlier suggested that when incapable or inexperienced subcontractors are employed, the quality of the final construction product could be sacrificed.

Among the various contracting and subcontracting literature available especially regarding building construction risk management (see Amoah and Pretorious, 2020; Rane, Potdar and Rane, 2019; Jarkas and Haupt, 2015; Hlaing et al., 2008), a key issue which is lacking is the impact of subcontractor risk management on the quality performance of building construction projects (Amoah and Pretorious, 2020). This issue is so because, for the majority of international studies conducted on risk management, the issue relating to the influence of subcontractor risk management on the quality performance of building construction is underreported. For instance, Ghosh and Jintanapakanont (2004) examined construction risk factors in large infrastructure projects in Thailand and reported that among the many risk factors, unavailability of funds, construction delay, the financial failure of the contractor, unclear scope of work, subcontractor failure and lack of an 
adequate number of staff for subcontractor were key. In the study by Wiguna and Scott (2005), the performance of building construction projects in Indonesia was reported to be affected by risk factors such as high inflation of prices, defective design, design change by the owner, defective construction work, and problems with the availability of labour, material and equipment. In China, Zou, Zhang and Wang (2007) revealed that because of the many risks associated with construction projects, clients, designers and government bodies were to take the responsibility of managing their potential risks, with emphasis on the employment of contractors and subcontractors with robust construction management knowledge and experience to minimise such risks. In Palestine, Enshassi, Mohamed and Abu Mosa (2008) also revealed the risk factors that impact construction project performance to include financial failure of the contractor, working in dangerous areas, poor communication among project parties, and unmanaged cashflows. Similar findings are reported in studies in the United Arab Emirates (El-Sayegh, 2008), Iran (Tadayon, Jaafar and Nasri, 2012), Malaysia (Goh and Abdul-Rahman, 2013), Ethiopia (Turkey, 2011 ) and Singapore (Hwang, Zhao and Ng, 2013), among others.

In a recent study, Amoah and Pretorious (2020) evaluated the impact of risk management on project performance in small construction firms in South Africa and found that such firms do not have laid down risk management processes which project teams are made to go through before and during the execution of their projects. In their study, it was again reported that there has not been any conclusive evidence regarding the impact of risk management on project performance (e.g., time, quality and cost), though it was acknowledged that there are certain identified risk events that caused project failures, of which subcontractor related issues was mentioned (Amoah and Pretorious, 2020). Since the new construction industry (accentuates subcontracting) is gaining popularity over the traditional construction industry, to improve productivity and quality (Rane, Potdar and Rane, 2019), there is the need to tackle issues such as the one under investigation to improve on risk management in the construction industry.

Dai et al. (2009) had earlier indicated that in the context of construction, risks are generally deemed as occurrences that influence the primary objectives of a project, e.g., cost, time, and quality. Since there have been numerous studies on risks associated with cost and time (such as those presented above), this study is specifically moulded around risks associated with quality. Again since "issues that pertain to project risks are subjective and highly susceptible to the unique political, economic, environmental and socio-cultural conditions of a country" (Perera et al., 2014: 3), this study concentrated on the phenomenon in the Ghanaian construction industry with lessons for other construction industries with similar political, economic, environmental and socio-cultural conditions. Following this gap, the research question which guided this study is "what is the influence of subcontractor risk management on the quality performance of building construction projects in Ghana?". To answer this question, the study aimed to empirically examine the impact subcontractor risk management has on the quality performance of building construction projects in Ghana. To achieve the goal of the study five objectives were set namely: (1) to determine the impact of financial risk from subcontracting on building construction quality performance, (2) to determine the impact of resource risk from subcontracting on building construction quality performance, (3) to determine the impact of technical risk from subcontracting on building construction quality performance, (4) to determine the impact of managerial risk from subcontracting on building construction quality performance 
and (5) to determine the impact of relationship risk from subcontracting on building construction quality performance. This article is divided into six sections and started with the background to the study. The next section reviews appropriate literature that leads to the formation of the key hypotheses used in the study. Next, the research methodology is reported, followed by the presentation of the results and discussion, after which the conclusion was drawn based on the outcome of the study in the final section.

\section{LITERATURE REVIEW}

\section{Development of Hypotheses}

It is a fact that extensive subcontracting activities pose risks to the general contractors, clients, and project management teams (Lew et al., 2018). Project risk is an uncertain event or condition that if occurs, has a positive or negative effect on a project's objectives (El-Karim, El Nawawy and Abdel-Alim, 2017). Nelson and Pritchard (2007) defined risk to mean the probability of something happening that can impact the performance of a project or at least one of the project objectives. Among the prevalent sources of uncertainties in construction projects are the performance of construction parties, resource availability, environmental conditions, the involvement of other parties, contractual relations, and the likes (Faridi and El-Sayegh, 2006). In the context of the construction industry, the risk could be the likelihood of the occurrence of a combination of events which occur during the whole process of construction to the detriment of the project (Faber, 1979). According to Hertz and Thomas (1983), construction risk is the lack of predictability about the structured outcome or consequences in a decision or planning situation.

The construction sector is full of risks related to planning, execution, communication and interaction with the surrounding society (Abderisak and Lindahl, 2015). These risks if not controlled can impact negatively the overall quality of the construction project. According to Kasapoğlu (2018), the well-known risks embedded in construction are health and safety issues, delivery schedules and aspects related to finances. Other researchers have also classified construction risks in various ways. El-Sayegh (2008) classified the risks in construction into internal and external. The internal risks were related to the company or project, and the external risks were related to the market or third parties. Also, Zayed, Amer and Pan (2008) classified risks into macro-level (financial, political, market, etc.) and microlevel (e.g., those related to the project such as contract, design, resources and quality). Other studies have further classified construction risk to include financial, contractual, market/industry, project, construction site-related, company, social, political, economic, legal, etc. (Alashwal and Al-Sabahi, 2018; De Lemos et al., 2004).

This study adopts the definition of risk as proposed by the PMI (Project Management Institute) (2013) and modifies it to define construction risk to include an uncertain event or condition, which may have a positive or negative effect on the quality performance of the construction project. Subcontracting as a condition or a requirement on building construction project carries with it various categories of project risks. These risks may affect various aspects of project performance if not well managed. Because of this, and following the review of literature, five hypotheses 
were developed to test the influence of subcontractor risk management on project quality performance. The hypotheses are discussed in the following sub-section.

\section{Subcontractor financial risk and building construction project quality performance}

Financial risks are a group of risks that affect construction firms in delivering outcomes (Fernando et al., 2017). According to labal et al. (2015), such risks are among the most influential factors that affect construction projects. Such risks are therefore considered to be critical for construction organisations (Ke et al., 2011). Perera, Dhanasinghe and Rameezdeen (2009) listed some of the financial risks associated with construction to include unavailability of funds from clients, fluctuations resulting from exchange rates, and the financial default of a subcontractor. In the view of Akintoye and MacLeod (1997), these risks are mainly associated with the health of the contractors' cash flow. Jorion (2009) indicated that financial risks have its roots in three basic sources: Market risk (losses resulting from the movements in financial market prices or volatilities), credit risk (losses that result from the unwillingness of counterparties to deliver their contractual obligations) and operational risk (those that result from failed or inadequate internal processes, systems, etc.). Issues related to financial risks are well reported in the literature. In Nigeria, financial risk is reported to be a major problem affecting the construction industry (Mansfield, Ugwu and Doran, 1994). Similar cases are mentioned in Kuwait by Kartam and Kartam (2001), Iran (Ghoddousi and Hosseini, 2012), Malaysia (Goh and Abdul-Rahman, 2013), Vietnam (Le-Hoai, Lee and Lee, 2008), Sri Lanka (Fernando et al., 2017), among other places. The inability to control this kind of risk may result in several issues including the refusal of contractors to rectify defects, asking for extra payments, filing for bankruptcy deliberately, time overruns, etc. (Fernando et al., 2017; Li, Arditi and Wang, 2015). For this reason, the study in achieving its goal sought to test the hypothesis that:

$\mathrm{H1}$ : Financial risk from subcontracting has an impact on building construction project quality performance.

\section{Subcontractor resource risk and building construction project quality performance}

The overall progress of a construction project can also be affected by the risk of resource unavailability. There are considerable risks involved in the material, equipment, and human resources in the construction industry (Zavadskas, Turskis and Tamošaitiene, 2010). This is even more pronounced when one looks at works of specialist nature as with works executed by subcontractors (domestic or nominated). Poorly managed logistics and inadequate use and tracking of resources are major subcontracting resource risk factors. According to Fisk (2003), the availability and productivity of the resources necessary to construct the project are risks that are proper for the contractor to assume. Resource risks include defective materials, availability of equipment, availability of labour and delayed site access (Tang et al., 2007). The study sought to investigate the impact of such risks of building construction quality performance in Ghana by testing the following hypothesis:

H2: Resource risk from subcontracting has an impact on building construction project quality performance. 


\section{Subcontractor technical risk and building construction project quality performance}

According to Jayasudha and Vidivelli (2016), technical risk is the inability to build a product that will satisfy requirements. Construction technical risks can be traced from the bidding phase through to the estimating process, hence, from the planning and scheduling of a project (Edwards and Bowen, 1998). Edwards and Bowen (1998) categorised design failure, failure of systems and equipment, errors in estimation as major technical risks. These risks can have a significant impact on the project if not identified and managed. The lack of technical advice for project actors could initiate all forms of technical risks during a construction project (Manelel and Muya, 2008). This is a major type of risk when subcontracting is employed. Changes in design and changes in construction method during the project are all technical errors that can have huge impacts on the cost, duration and quality of a construction project hence the following hypothesis:

H3: The technical risk from subcontracting has an impact on building construction project quality performance.

\section{Subcontractor managerial risk and building construction project quality}

Low management competency of subcontractors is one of the recognised key risks related to subcontractors. Unlike a general contractor who continuously manages a construction site for a long period, subcontractors normally allocate their manpower and other resources to different projects to achieve a maximum profit of their own business. Accordingly, in addition to specialist abilities, the management competency should be regarded as one of the key criteria for appointing subcontractor's knowledge about the project development environment, local regulations and other governing bodies such as unions. Subcontractors must understand the scope of the project and deploy appropriate resources including assuming full responsibility for seamless development under the direction and management of the client (Mullins, 2005). Low productivity, quality assurance, cost control and human resource management can all be categorised under managerial risks (Edwards and Bowen, 1998). Alashwal and Al-Sabahi (2018) list managerial risks to include project delay/cost overrun, delay of owner consent of work commencing, insufficient staff and consultants, unreasonably imposed tight schedule, delay of drawings and regulatory approvals, among others. The success of every construction project depends on both internal and external stakeholders' performance. The management capability of a project manager has a huge impact on the successful outcome of the project (Aje, 2012). The management risks adopted for this study are incompetent consultants and contractors and poorquality performance control. The study, sought to test the following hypothesis:

H4: The managerial risk from subcontracting has an impact on building construction quality performance.

\section{Subcontractor relationship risk and building construction project quality performance}

Subcontractor relationship risk refers to the issues surrounding the long-term working relationships and the behavioural implications such as organisational behaviour, defects liability attitudes, stress and impacts of working relationships among parties 
in the project (Al-Hammad, 2000). It has been established that the success of construction projects in relation to timely completion is significantly affected by the effectiveness of communication between the contractor and his subcontractors. Inappropriate means of sharing and disseminating information among project parties may seriously impede the headway for work (Al-Hammad, 2000). When contractors poorly communicate information to their subcontractors, it is a recipe for wrongful pricing. Shafii, Ali and Othman (2006) raised concerns that main contractors usually mount pressure on the subcontractor to reduce prices and yet essential information that would have aided in the subcontractor's decision-making is held back; making it difficult for proper pricing and working. The relationship and coordination among construction project stakeholders can be very supportive or on the other side antagonistic (Lester, 2007). However, the project manager must ensure he manages them effectively and efficiently. The main forms of relationshiprelated risks could be poor communication, amongst the project team, lack of commitment and poor organisation and coordination. The study sought to test the following hypothesis to investigate the relationship between this risk and building construction project quality performance:

H5: Relationship risk from subcontracting has an impact on building construction quality performance.

\section{RESEARCH METHODOLOGY}

In consideration of the philosophical worldview of positivism, the research design adopted for this research is the quantitative design. The research is based on the deductive approach as it involves the collection of quantitative data for measurement to confirm variables identified from concepts based on the philosophical position in terms of the underlying relationships of the variable in this study; that is risk management and quality performance. Following the extensive review of the literature concerning the key issues under investigation, a structured questionnaire was developed.

\section{Survey Design}

Based on an extensive review of literature, a draft questionnaire was developed for the study and was first piloted among 26 selected Heads of Works for Metropolitan, Municipal and District Assemblies (MMDAs) in Ghana. The 26 Heads of Works were those with at least 10 years of working experience in any MMDA. They were asked to assess how suitable the questions were concerning the subject under discussion. This they did by either deleting or adding onto the questions posed to authenticate its peculiarity to the situation under investigation. A final version of a closed-ended questionnaire was therefore prepared following the feedback from the piloting. The various components with the associated variables and literature sources are shown in Table 1. From the literature survey, 19 variables were identified and further classified under 5 components (based on the 5 hypotheses to be tested) to include: technical risks $\left(C_{T}\right)$, financial risks $\left(C_{F}\right)$, resource risks $\left(C_{R}\right)$, managerial risks $\left(C_{M}\right)$ and relationship risks $\left(C_{L}\right)$. There were 5 variables $\left(C_{T 1}\right.$ to $\left.C_{T 5}\right)$ identified under the technical risks while 4 variables $\left(C_{F 1}\right.$ to $\left.C_{F 4}\right)$ were identified under financial risks, 3 variables $\left(C_{R 1}\right.$ to $\left.C_{R 3}\right)$ were identified under resource risks, 4 variables $\left(C_{M 1}\right.$ to $\left.C_{M 4}\right)$ 
were identified under managerial risks and 3 variables $\left(C_{L 1}\right.$ to $\left.C_{L 3}\right)$ were identified under relationship risks. The questionnaire was made up of two sections (Sections $A$ and $B$ ). Section A required the respondents to indicate their background information. Section B required respondents to score on a Likert scale of 1 to 5 (where 1 = "Strongly Disagree"; 5 = "Strongly Agree") their levels of agreement with the questions asked.

Table 1. Components and Variables

\begin{tabular}{|c|c|c|}
\hline Code & Component & Sources of Variables \\
\hline \multicolumn{3}{|c|}{ Technical risks } \\
\hline $\mathrm{C}_{\mathrm{T} 1}$ & Inadequate project formulation & \multirow{5}{*}{$\begin{array}{l}\text { Jayasudha and Vidivelli (2016), } \\
\text { Manelel and Muya (2008) and } \\
\text { Edwards and Bowen (1998). }\end{array}$} \\
\hline $\mathrm{C}_{\mathrm{T} 2}$ & Poor specification & \\
\hline $\mathrm{C}_{\mathrm{T} 3}$ & System and equipment failure & \\
\hline $\mathrm{C}_{\mathrm{T} 4}$ & Error in price estimation & \\
\hline $\mathrm{C}_{\mathrm{T5}}$ & Design changes & \\
\hline \multicolumn{3}{|c|}{ Financial risks } \\
\hline $\mathrm{C}_{\mathrm{F} 1}$ & Poor financial appraisal & \multirow{4}{*}{$\begin{array}{l}\text { Fernando et al. (2017), labal et al. } \\
\text { (2015), Li, Arditi and Wang (2015), } \\
\text { Goh and Abdul-Rahman (2013), } \\
\text { Ghoddousi and Hosseini (2012), Ke } \\
\text { et al. (2011), Perera, Dhanasinghe } \\
\text { and Rameezdeen (2009), Jorion } \\
\text { (2009), Le-Hoai, Lee and Lee (2008), } \\
\text { Kartam and Kartam (2001), Akintoye } \\
\text { and MacLeod (1997) and Mansfield, } \\
\text { Ugwu and Doran (1994). }\end{array}$} \\
\hline $\mathrm{C}_{\mathrm{F} 2}$ & Payment delays & \\
\hline $\mathrm{C}_{\mathrm{F} 3}$ & Errors in cash flow forecast & \\
\hline $\mathrm{C}_{\mathrm{F} 4}$ & Unrealistic price estimation & \\
\hline \multicolumn{3}{|c|}{ Resource risks } \\
\hline$C_{R 1}$ & Shortage of staff & \multirow{3}{*}{$\begin{array}{l}\text { Zavadskas, Turskis and Tamošaitiene } \\
\text { (2010), Tang et al. (2007) and Fisk } \\
\text { (2003). }\end{array}$} \\
\hline $\mathrm{C}_{\mathrm{R} 2}$ & Shortage of materials & \\
\hline $\mathrm{C}_{\mathrm{R} 3}$ & Shortage of plants & \\
\hline \multicolumn{3}{|c|}{ Managerial risks } \\
\hline $\mathrm{C}_{\mathrm{M} 1}$ & Improper planning by the contractor & \multirow{4}{*}{$\begin{array}{l}\text { Alashwal and Al-Sabahi (2018), Aje } \\
\text { (2012), Mullins (2005), Edwards and } \\
\text { Bowen (1998) }\end{array}$} \\
\hline $\mathrm{C}_{\mathrm{M} 2}$ & Incompetent sub-contractors & \\
\hline $\mathrm{C}_{\mathrm{M} 3}$ & Poor quality and performance control & \\
\hline $\mathrm{C}_{\mathrm{M} 4}$ & Improper communication skills & \\
\hline \multicolumn{3}{|c|}{ Relationship risks } \\
\hline $\mathrm{C}_{\mathrm{L} 1}$ & $\begin{array}{l}\text { Poor communication amongst project } \\
\text { team }\end{array}$ & \multirow[t]{3}{*}{$\begin{array}{l}\text { Lester (2007), Shafii, Ali and Othman } \\
\text { (2006) and Al-Hammad (2000). }\end{array}$} \\
\hline $\mathrm{C}_{\mathrm{L} 2}$ & Lack of commitment & \\
\hline$C_{L 3}$ & Poor organisation and co-ordination & \\
\hline
\end{tabular}




\section{Population and Sample Size}

The field study was performed with Heads of Works for MMDAs in Ghana who made up the population. The Head of Works is the official project manager for government initiated projects in the MMDAs. He can, nominate a subcontractor depending on the requirement of the project. Furthermore, all work sections done by subcontractors on projects are subject to his approval. There were 260 MMDAs in Ghana at the time of the study, therefore, there were essentially 260 Heads of Works at the MMDAs. Out of the 260 Heads of Works at MMDAs, 26 were selected for the piloting leaving 234 Heads of Works. The census sampling technique was therefore adopted to include all the remaining Heads of MMDAs. Out of the 234 questionnaires distributed, 139 questionnaires were retrieved representing a response rate of $59.40 \%$ which was deemed adequate for the study.

\section{Data Analysis}

Structural equation modelling (SEM) analytical tool was adopted. Hair et al. (2016) recommended that the sample size should be equal or greater than 10 times the largest number of structural paths directed at a specific construct in the structural model. The construct with the highest number of structural paths directing to it is "technical risk" which had 5 paths. Therefore, adopting the widely used "10 times rule" a minimum sample size of 50 was required for the research. This study adopted the partial least squares structural equation modelling (PLS-SEM) because the research is explanatory, predictive, and comprises of both reflective and formative variables (Kwofie, Adinyira and Fugar, 2016; Asman et al., 2019).

\section{RESULTS}

This section presents the results of the analyses on the correlation between factors of subcontractor risks and quality performance in construction project management and the extent of the impact of risk factors on quality performance in construction project management. The PLS-SEM analysis was carried out per the guidelines and sequence suggested by Hair et al. (2014) and Sarstedt et al. (2016). This involves the evaluation of the reflective measurement model and the evaluation of the structural model. The assessment of the reflective measurement model involves the evaluation of internal reliability and validity and the average variance extracted (AVE). The assessment of the structural model involves the evaluation of the predictive ability of the model which involves determining the coefficient of determination $\left(R^{2}\right)$ and assessing the path coefficients (Sarstedt et al., 2014).

According to Hair et al. (2016), constructs with low internal consistency and reliability can be improved through the elimination of indicators with low outer loadings. Indicators with outer loadings between 0.400 and 0.699 should be considered for elimination but indicators with outer loadings below 0.40 should all the time be eliminated from the scale. However, researchers should carefully consider the consequence of the elimination of indicators. Indicators deleted must aid in the improvement of the internal consistency and reliability of the constructs. However, after conducting the outer loading relevance testing criterion, the results showed no need to eliminate any indicator. 
The Cronbach's alpha gives an estimate of the reliability of the construct based on the inter-correlations of the observed indicator variables (Straub, Boudreau and Gefen, 2004). Researchers have reported on acceptable values of Cronbach's alpha ranging from 0.700 to 0.950 (DeVellis, 2003; Kwofie, Adinyira and Fugar, 2016; Agyekum, Simons and Botchwey, 2018; Agyekum et al., 2020). From Table 2, the Cronbach's alphas for the constructs ranged from 0.732 to 0.884 . Therefore, all the variables met the acceptable values of Cronbach's alpha as stipulated by DeVellis (2003). However, Cronbach's alpha has a major flaw which is its dependency on the number of items in the scale (Streiner and Norman, 1989). Thus, a scale can be made to appear more correlated simply by doubling the number items even though the average correlation remains the same. Due to this, a more suitable check for internal consistency used by PLS-SEM was adopted to supplement the Cronbach's alpha ratios. These are composite reliability and AVE.

According to Straub, Boudreau and Gefen (2004), the composite reliability considers the different outer loadings of the indicator variables. The values of composite reliability range from 0 to 1 with values closer to 1 depicting higher reliability. Hair et al. (2014) recommended a composite reliability value of 0.700 and above to be appropriate. In Table 2, the composite reliability values range from 0.849 to 0.916 which depicts a satisfactory internal consistency and reliability. Furthermore, in assessing the internal consistency and reliability of the constructs, AVE was employed. Hair et al. (2016) recommended a threshold of 50\% for AVE values. Thus, AVE values must be greater than 0.50. From Table 2, the AVE values range from 0.617 to 0.686 which also depicts a satisfactory level of internal consistency and reliability. The composite reliability values and AVE values displayed in Table 2 indicates that all the measures were internally consistent.

\section{Discriminant Validity}

Hair et al. (2016) described the discriminant validity as the degree to which a construct deviates from other constructs by empirical standards. This means that the establishment of discriminant validity denotes that, a construct is exceptional and represents singularities not represented by any other construct in the model. The discriminant validity can be checked on two different levels namely; the indicator level and the construct level. The cross-loadings technique is adopted for the indicator level discriminant validity while the Fornell-Larcker criterion is used for the construct level criterion. Hair, Ringle and Sarstedt (2011) indicated that the cross-loading technique is more liberal as it is likely to indicate that the constructs exhibit discriminant validity thus, the Fornell-Larcker criterion is more appropriate tool for assessing discriminant validity. Therefore, the Fornell-Larcker criterion was adopted.

The Fornell-Larcker criterion is used to check the discriminant validity at the construct level. The square root of AVE of each construct should be higher than its highest correlation with any other construct. The results showed that the discriminant validity of the measurement model at both indicator and construct levels was enough. 
Table 2. Factor Loading, Cronbach's Alpha Composite Reliability and AVE

\begin{tabular}{|c|c|c|c|c|c|}
\hline No. & Risks & Loadings & $\begin{array}{l}\text { Cronbach's } \\
\text { Alpha }\end{array}$ & $\begin{array}{l}\text { Composite } \\
\text { Reliability }\end{array}$ & AVE \\
\hline B & Quality performance & - & 0.884 & 0.916 & 0.686 \\
\hline 1 & Monitoring and feedback & 0.831 & & & \\
\hline 2 & Top management support & 0.881 & & & \\
\hline 3 & Effective quality planning & 0.875 & & & \\
\hline 4 & Effective quality assurance & 0.790 & & & \\
\hline 5 & Effective quality control & 0.755 & & & \\
\hline $\mathrm{C}_{\mathrm{T}}$ & Technical risks & - & 0.861 & 0.900 & 0.645 \\
\hline 1 & Inadequate project formulation & 0.736 & & & \\
\hline 2 & Poor specification & 0.723 & & & \\
\hline 3 & System and equipment failure & 0.850 & & & \\
\hline 4 & Error in price estimation & 0.836 & & & \\
\hline 5 & Design changes & 0.861 & & & \\
\hline$C_{F}$ & Financial risks & - & 0.882 & 0.881 & 0.650 \\
\hline 6 & Poor financial appraisal & 0.849 & & & \\
\hline 7 & Payment delays & 0.734 & & & \\
\hline 8 & Errors in cash flow forecast & 0.809 & & & \\
\hline 9 & Unrealistic price estimation & 0.828 & & & \\
\hline$C_{R}$ & Resource risks & - & 0.732 & 0.849 & 0.652 \\
\hline 10 & Shortage of staff & 0.840 & & & \\
\hline 11 & Shortage of materials & 0.750 & & & \\
\hline 12 & Shortage of plants & 0.830 & & & \\
\hline$C_{M}$ & Managerial risks & - & 0.792 & 0.865 & 0.617 \\
\hline 13 & $\begin{array}{l}\text { Improper planning by the } \\
\text { contractor }\end{array}$ & 0.782 & & & \\
\hline 14 & Incompetent sub-contractors & 0.710 & & & \\
\hline 15 & $\begin{array}{l}\text { Poor quality and performance } \\
\text { control }\end{array}$ & 0.782 & & & \\
\hline 16 & Improper communication skills & 0.862 & & & \\
\hline$C_{L}$ & Relationship risks & - & 0.763 & 0.861 & 0.674 \\
\hline 17 & $\begin{array}{l}\text { Poor communication amongst } \\
\text { project team }\end{array}$ & 0.732 & & & \\
\hline 18 & Lack of commitment & 0.871 & & & \\
\hline 19 & $\begin{array}{l}\text { Poor organisation and co- } \\
\text { ordination }\end{array}$ & 0.854 & & & \\
\hline
\end{tabular}


Table 3. Fornell-Lacker Criterion

\begin{tabular}{lcccccc}
\hline & $\mathbf{1}$ & $\mathbf{2}$ & $\mathbf{3}$ & $\mathbf{4}$ & $\mathbf{5}$ & $\mathbf{6}$ \\
\hline Financial risk & 0.806 & & & & & \\
Managerial risk & 0.698 & 0.786 & & & & \\
Quality performance & 0.728 & 0.768 & 0.828 & & & \\
Relationship risk & 0.622 & 0.714 & 0.722 & 0.821 & & \\
Resource risk & 0.783 & 0.752 & 0.802 & 0.717 & 0.808 & \\
Technical risk & 0.694 & 0.736 & 0.812 & 0.702 & 0.746 & 0.803 \\
\hline
\end{tabular}

\section{Assessment of the Structural Model}

This section explains the evaluation of the structural model. Evaluation of the structural model aids in determining the extent to which the empirical data support the hypotheses. In the assessment of the structural model, Sarstedt et al. (2014) suggested the use of the coefficient of determination $\left(R^{2}\right)$ and assessment of the path coefficients. Furthermore, the significance of the relationships must be assessed from the bootstrapping results.

Table 4. Coefficient of Determination $\left(R^{2}\right)$ and Their Effects

\begin{tabular}{cc}
\hline $\boldsymbol{R}^{2}$ Values & Effects \\
\hline 1.00 to 0.51 & Substantial \\
0.50 to 0.26 & Moderate \\
0.25 to 0.00 & Weak \\
\hline
\end{tabular}

Source: Sarstedt et al. (2014)

The coefficient of determination $\left(R^{2}\right)$ is the commonly adopted measure for a structural model. Hair et al. (2012) described the $R^{2}$ value as the amount of explained variance of each endogenous latent variable by an exogenous latent variable. Furthermore, the $R^{2}$ value represents the predictive accuracy of the model. The threshold and effects of $R^{2}$ values as suggested by Sarstedt et al. (2014) are shown in Tables 4. Inferring from Tables 4 and 5, it can be deduced that all the dependent variables had a substantial predictive effect.

Table 5. $R^{2}$ for the Dependent Variables

\begin{tabular}{lcc}
\hline Dependent Variables & $\mathbf{R}^{2}$ Values & Effects \\
\hline Quality performance & 0.854 & Substantial \\
\hline
\end{tabular}

To make inferences about the hypotheses, the path coefficients and significance level need to be calculated. These values are calculated in the SmartPLS software by a process called bootstrapping. Bootstrapping was described by Hair et al. (2016), as a non-parametric process that aids in ascertaining the statistical significance of various PLS-SEM results. The bootstrapping calculation was undertaken with a bootstrap sample of 5,000 and at a confidence level of 
5\% ( $\alpha=0.05$; two-tailed test). Therefore, a t-value above 1.96 indicates that the hypothesis is statistically supported. Table 6 shows a summary of path coefficients and significance levels.

Table 6. Summary of Path Coefficients and Significance Levels

\begin{tabular}{cccc}
\hline Paths & Path Coefficients & t-Statistics & Inference \\
\hline H1 & 0.226 & 3.676 & Supported \\
H2 & 0.244 & 3.475 & Supported \\
H3 & 0.344 & 4.681 & Supported \\
H4 & 0.204 & 3.610 & Supported \\
H5 & 0.019 & 0.357 & Not Supported \\
\hline
\end{tabular}

From the results, the final model arrived at is shown in Figure 1. Figure 1 shows the relationship between sub-contractor risk and project quality performance. The circular shapes depict the main criteria while the rectangular shapes depict the sub-criteria. The straight lines depict the relationships between the various criteria and sub-criteria.

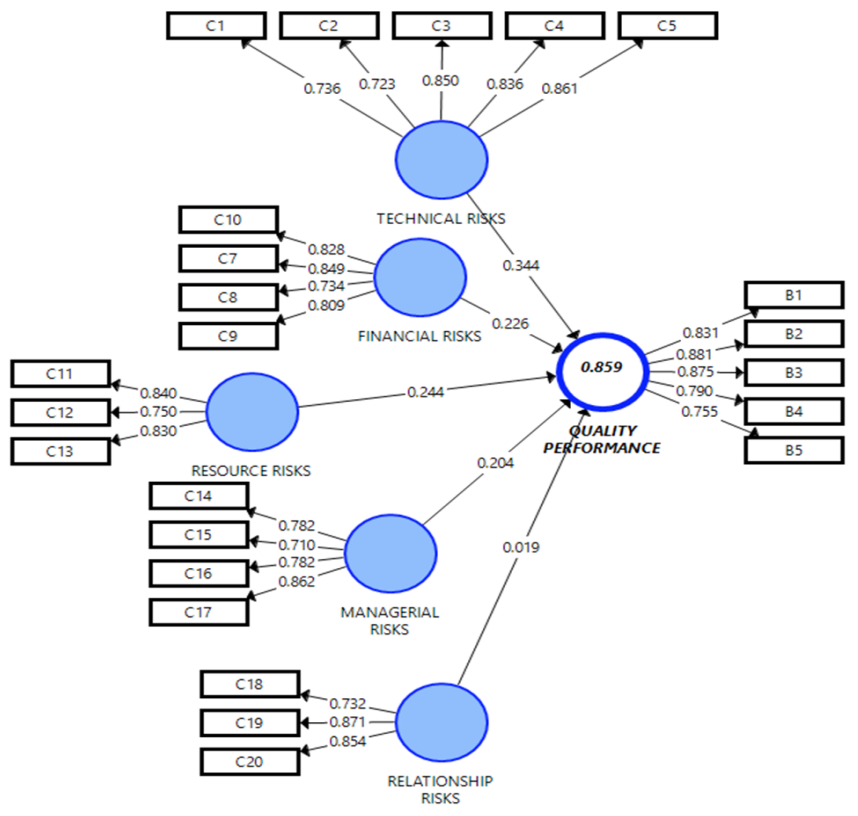

Figure 1. Final Model

Note: B1: Monitoring and feedback; B2: Top management support; B3: Effective quality planning; B4: Effective quality assurance; B5: Effective quality control; Cl: Inadequate project formulation; C2: Poor specification; C3: System and equipment failure; C4: Error in price estimation; C5: Design changes; C6: Poor financial appraisal; C7: Payment delays; C8: Errors in cash flow forecast; C9: Unrealistic price estimation; C10: Shortage of staff; C11: Shortage of materials; C12: Shortage of plants; C13: Improper planning by the contractor; C14: Incompetent sub-contractors; C15: Poor quality and performance control; C16: Improper communication skills; C17: Poor communication amongst project team; C18: Lack of commitment; C19: Poor organisation and co-ordination. 


\section{DISCUSSION}

\section{Relationship between Endogenous Latent Variables and Relationship with the Exogenous Latent Variables}

\section{H1: Impact of financial risk from subcontracting on building construction quality performance}

Financial risk from subcontracting had 4 indicators and it showed a significant impact on construction quality performance $(\beta=0.226 ; t=3.676, \alpha>0.05)$. Therefore, it supports the hypothesis that "Financial risk from subcontracting has an impact on building construction quality performance". This finding agrees with the literature. The success of a construction project relies heavily on the proper management of financial risk (Fernando et al., 2017). Financial viability refers to the issues surrounding the working and operating capitals, yearly turnover, labour force turn around and retention rates, recruitment process and overall employee's wellbeing (Al-Hammad, 2000). Since financial risk has an impact on quality performance, safeguarding against such risks from the side of subcontractors is crucial for project quality and for that matter overall project success (Chen et al., 2010). Fernando et al. (2017) further iterated that such risk can drive a construction company to bankruptcy. The general underdevelopment and underperformance of construction companies in most developing countries are a result of financial shortcomings and cash flow problems. This is not only seen with main contractors but among subcontractors as well. Zedan and Martin (1995) opined that the financial status of the subcontractor can affect its performance. The quality of the end-product is hugely affected by the financial capabilities of the subcontractor (Abdul-Rahman et al., 2011). As stated earlier by Li, Arditi and Wang (2015), failing to address financial risks can create serious problems in the construction industry.

\section{H2: Impact of resource risk from subcontracting on building construction quality performance}

Resource risks of a sub-contractor also showed significant impact on construction quality performance $(\beta=0.244 ; t=3.475, \alpha>0.05)$. Therefore, it supports the hypothesis that "Resource risk from subcontracting has an impact on building construction quality performance". Resource risks are part of the risk factors that originate from within the project. Unavailability of resources to continue a project can affect the effectiveness of delivery. Husin et al. (2017) indicated that such project resources risks include human resources, materials, and equipment. For instance, in the case of human resources, their experience is a significant contributor to high-quality performance. Zedan and Martin (1995) opined that, if the human factor of resources is not technically capable of executing the project, it generally affects the quality of the project. Therefore, the lack of such a resource can pose a risk that can affect the quality of the project as shown by the results from the analysis. Studies have shown that the human resource risk variables can include labour availability, capacity and productivity issues, worker discipline, worker wages, synergies in work teams, strikes, and overwork turnover (Husin et al., 2017; da-Silva and Crispim, 2014). 
Risk factors associated with a material resource may also include material prices, ordering processes, shipping and storage, material theft, volume and quality of materials, limited material storage among others (Husin et al., 2017; daSilva and Crispim, 2014). The variables involved in equipment resource risks may include equipment capacity, placement, mobilisation, malfunction, productivity and efficiency, and the likes (Husin et al., 2017; da-Silva and Crispim, 2014). It is therefore in the right order if the findings from this study revealed that resource risk emanating from subcontracting has an impact on the quality performance of construction works. With the impact of project resource risk well documented in the literature, main contractors should design the project resource management strategy considering subcontractor's resource management. Husin et al. (2017) suggested that human resource risks could be controlled by considering various aspects of availability, ability, and work control. Also, to control material resource risks, the material factors could be refined in relation to procurement strategy, security and material handling, right from the distribution through to the usage phase (Husin et al., 2017). The equipment related risks could also be controlled when management decides to apply good equipment management strategies (Husin et al., 2017).

\section{H3: Impact of technical risk from subcontracting on building construction quality performance}

Technical risk of a sub-contractor displayed a significant effect on construction quality performance $(\beta=0.344 ; t=4.681, \alpha>0.05)$. Therefore, it supports the hypothesis that "Technical risk from subcontracting has an impact on building construction quality performance". The complex, demanding and dynamic nature of the construction industry calls for project managers with the needed expertise that can manage the construction process right from inception to completion. The consequence of a mismatch of skills and project complexity could lead to loss of control and consequently failure of the project (Mouchi, 2011). This situation also holds for subcontractors. Technical skills are therefore important to achieve quality in the construction process. Technical risk is defined as the inability to build a product that will satisfy requirements (Jayasudha and Vidivelli, 2016). Alashwal and Al-Sabahi (2018) list such risks to include a defect in material quality, lack of appropriate infrastructure and technology, defective designs, machinery breakdown, errors in estimating the cost of projects, unclear or incomplete specifications, lack of technical knowledge of staff among others. Edwards and Bowen (1998) also categorised these kinds of risks into design failure, failure of systems and equipment, and errors in estimation. These risks when sourced from the subcontractor can have a significant impact on the project if not identified and managed by the main contractor. The lack of technical advice for project actors could initiate all forms of technical risks during a construction project (Manelel and Muya, 2008). Zedan and Martin (1995) indicated that the quality of a construction project is affected by the technical abilities of the sub-contractor. Therefore, the results corroborate the findings from other studies. 


\section{H4: Impact of managerial risk from subcontracting on building construction quality performance}

Managerial risk of a sub-contractor had a significant effect on construction quality performance $(\beta=0.204 ; t=3.610, \alpha>0.05)$. Therefore, it supports the hypothesis that "Managerial risk from subcontracting has an impact on construction quality performance". Unlike a general contractor who continuously manages a construction site for a long period, subcontractors normally allocate their manpower and other resources to different projects to achieve a maximum profit of their own business. Without competent management skills, subcontractors cannot manage their resources to meet the needs from several concurrent construction sites which may consequently affect the quality of the project. Aje (2012) pointed out that, the poor management capabilities of subcontractors can affect the quality of work done by them. Alashwal and AI-Sabahi (2018) indicated that project cost overrun, lack of supervision and control, delay of government approvals, shortage of skilled workers, delay of drawings and regulatory approvals, unreasonably imposed tight schedules and insufficient staff and consultants are all managerial risks that could be controlled to improve on project quality. Charoenngam and Yeh (1999) postulated that inefficiency of owner supervisors, the productivity of equipment and labour disputes are managerial risks that can create problems with productivity and quality assurance on-site. Lu and Yan (2013) also indicated that lack of effective communication among project partners can affect productivity and therefore the quality of the project outcome. Other studies also list theft, organizational relationships, lack of insurance of major equipment, among other things to be key managerial risks which should be controlled to achieve quality in the construction process (Kasapoğlu, 2018).

\section{H5: Impact of relationship risk from subcontracting on building construction quality performance}

Relationship risk of a sub-contractor exhibited an insignificant effect on construction quality performance $(\beta=0.019 ; t=0.357, \alpha>0.05)$. Therefore, the hypothesis that "Relationship risk from subcontracting has an impact on building construction quality performance" was not supported. It has been established that the success of a construction project in relation to timely completion is significantly affected by the effectiveness of communication between the contractor and his subcontractors. Inappropriate means of sharing and disseminating information among project parties may seriously impede the headway for work (Al-Hammad, 2000). Furthermore, Doloi (2009) indicated that poor relationships with subcontractors may affect the quality of workmanship and the quality of work executed. Unfortunately, results from this study do not support these assertions. The relationship among project stakeholders is a key issue in construction project execution, however, the quality of work is not affected by poor relationships as indicated by the results of the study. The relationship between main contractors and subcontractors in this part of the world (e.g., Ghana) tends to take two extreme forms, e.g., very formal and very informal. Subcontractors typically see the rather informal relationship with main contractors as the preferred. Most main contractors also prefer a very formal type of communication. But from the study, the respondents were of the view that whichever form of relationship the main contractors decide to adopt does not determine the eventual quality performance of the project. 


\section{CONCLUSIONS}

This study aimed at examining the influence of subcontractor risk management on the quality performance of building construction projects. To achieve this aim, five objectives were set based on the proposed hypotheses. The five objectives were to determine: (1) the impact of financial risk from subcontracting on building construction quality performance, (2) the impact of resource risk from subcontracting on building construction quality performance, (3) the impact of technical risk from subcontracting on building construction quality performance, (4) the impact of managerial risk from subcontracting on building construction quality performance and (5) the impact of relationship risk from subcontracting on building construction quality performance. Following an extensive review of literature, a questionnaire survey was conducted among 139 Heads of Works for MMDAs in Ghana. From the findings, it was revealed that four (financial risks, resource risks, technical risks, and managerial risks) out of the five hypotheses positively influenced the quality performance of construction projects. The findings again revealed that there was no significant impact of relationship risks on the quality performance of construction projects.

The finding as reported in this study has several implications, both theoretically and practically. Theoretically, a background for conducting an impact analysis (impact of project quality) of subcontractor risk on building construction projects has been created by this study. This will aid in prioritising significant subcontractor risks based on their impact (on quality)/probability matrix. Furthermore, this study has established the relationship between subcontractor risk management and building construction quality performance. Also, this study has provided empirical evidence for the need to effectively manage subcontractor risk as it can affect the quality of the construction project. Practically, the finding advances efforts at understanding the link between sub-contractor management and project performance with a focus on the management of risks emanating from the use of subcontractors on building projects. It has been discovered that in the selection of a subcontractor (domestic or nominated), the technical abilities of that subcontractor must be treated with high priority as the risk of low technical capabilities significantly affect construction quality performance.

The study was limited to empirically determining the relationship between subcontractor risks management and building construction project quality performance in Ghana. It did not go into how these risk factors could be managed to attain good quality performance of construction works. Again, it was limited to building projects leaving out other construction project typologies like road constriction, bridge construction, etc. It is argued that, to successfully manage and deliver construction projects, one has to gain a precise understanding of the characteristics and particularities of that project (Adinyira, Ahadzie and Kwofie, 2013; Kwofie et al., 2014). It is therefore recommended that going forward, future studies should be conducted on other project typologies and also into the development of a model for sub-contractor risk management in the Ghanaian construction industry given that the study has proven the positive link between sub-contractor management and project performance on building construction projects. 


\section{REFERENCES}

Abderisak, A. and Lindahl, G. (2015). Take a chance on me? Construction client's perspectives on risk management. Procedia Economics and Finance, 21: 548-554. https://doi.org/10.1016/S2212-5671(15)00211-7.

Abdul-Rahman, H., Wang, C., Takim, R. and Wong, S. (2011). Project schedule influenced by financial issues: Evidence in the construction industry. Scientific Research and Essays, 6(1): 205-212. https://doi.org/10.5897/SRE10.989.

Adinyira, E., Ahadzie, D.K. and Kwofie, T.E. (2013). Determining the unique features of mass housing projects (MHPs). In Proceedings of the 5th West Africa Built Environment Research (WABER) Conference. Accra, Ghana: WABER.

Agyekum, K., Kissi, E., Danku, J.C., Ampratwum, G. and Amegatsey, G. (2020). Factors driving the career progression of construction project managers. Journal of Engineering, Design and Technology, 18(6): 1773-1791. https://doi.org/10.1108/JEDT-09-2019-0242.

Agyekum, K., Simons, B. and Botchwey, S.Y. (2018). Factors influencing the performance of safety programmes in the Ghanaian construction industry. Acta Structilia, 25(2): 39-61. https://doi.org/10.18820/24150487/as25i2.2.

Aje, I. (2012). The impact of contractors' prequalification on construction project delivery in Nigeria. Engineering, Construction and Architectural Management, 19(2): 159-172. https://doi.org/10.1108/09699981211206098.

Akintoye, A. and MacLeod, M. (1997). Risk analysis and management in construction. International Journal of Project Management, 15(1): 31-38. https://doi.org/ 10.1016/S0263-7863(96)00035-X.

Alashwal, A.M. and Al-Sabahi, H. (2018). Risk factors in construction projects during unrest period in Yemen. Journal of Construction in Developing Countries, 23(2): 43-62. https://doi.org/10.21315/jcdc2018.23.2.4.

Al-Hammad, A.M. (2000). Common interface problems among various construction parties. Journal of Performance of Constructed Facilities, 14(2): 71-74. https://doi.org/10.1061/(ASCE)0887-3828(2000)14:2(71).

Amoah, C. and Pretorious, L. (2020). Evaluation of the impact of risk management on project performance in small construction firms in South Africa: The case of construction systems. Journal of Engineering, Design and Technology, 18(3): 61 1-634. https://doi.org/10.1108/JEDT-06-2018-0098.

Asman, G.E., Kissi, E., Agyekum, K., Baiden, B.K. and Badu, E. (2019). Critical components of environmentally sustainable buildings design practices of office buildings in Ghana. Journal of Building Engineering, 26: 100925. https://doi.org/10.1016/j.jobe.2019.100925.

Awwad, R., El-Souki, O. and Jabbour, M. (2016). Construction safety practices and challenges in a Middle Eastern developing country. Safety Science, 83: 1-11. https://doi.org/10.1016/j.ssci.2015.10.016.

Charoenngam, C. and Yeh, C.-Y. (1999). Contractual risk and liability sharing in hydropower construction. International Journal of Project Management, 17(1): 29-37. https://doi.org/10.1016/S0263-7863(97)00064-1.

Chen, J., Yang, L., Su, M. and Lin, J. (2010). A rule extraction-based approach in predicting derivative use for financial risk hedging by construction companies. Expert Systems with Applications, 37(9): 6510-6514. https://doi.org/10.1109/ ICIII.2011.101. 
Chiang, Y.H. (2009). Subcontracting and its ramifications: A survey of the building industry in Hong Kong. International Journal of Project Management, 27(1): 80-88. https://doi.org/10.1016/j.ijproman.2008.01.005

Choudhry, R.M., Hinze, J.W., Arshad, M. and Gabriel, H.F. (2012). Subcontracting practices in the construction industry of Pakistan. Journal of Construction Engineering Management, 138(12): 1353-1359. https://doi.org/10.1061/ (ASCE)CO.1943-7862.0000562.

Dai, J., Goodrum, P., Maloney, W. and Srinivasan, C. (2009). Latent structures of the factors affecting construction labour productivity. Journal of Construction Engineering and Management, 135(5): 397-406. https://doi.org/10.1061/ (ASCE)0733-9364(2009) 135:5(397).

da-Silva, L.H.R. and Crispim, J.A. (2014). The project risk management process: A preliminary study. Procedia Technology, 16(2014): 943-949. https://doi .org/10.1016/j.protcy.2014.10.047.

De Lemos, T., Eaton, D., Betts, M. and de Almeida, L.T. (2004). Risk management in the Lusoponte concession: A case study of the two bridges in Lisbon, Portugal. International Journal of Project Management, 22(1): 63-73. https://doi.org/10.1016/S0263-7863(03)00013-9.

DeVellis, R. (2003). Scale Development: Theory and Applications. Thousand Okas, CA: Sage.

Doloi, H. (2009). Analysis of pre-qualification criteria in contractor selection and their impacts on project success. Journal of Construction Management and Economics, 27(12):1245-1263. https://doi.org/10.1080/01446190903394541.

Edwards, P.J. and Bowen, P.A. (1998). Risk and risk management in construction: Review and future directions for research. Engineering Construction and Architectural Management, 4(1): 339-349. https://doi.org/10.1046/J.1365 $-232 X .1998 .54072 . x$.

El-Karim, M.S.B.A.A, El Nawawy, O.A.M and Abdel-Alim, A.M. (2017). Identification and assessment of risk factors affecting construction projects. HBRC Journal, 13: 202-216. https://doi.org/10.1016/j.hbrcj.2015.05.001.

El-Kholy, A.M. (2019). A new technique for subcontractor selection by adopting choosing by advantages. International Journal of Construction Management, Forthcoming. http://doi.org/10.1080/15623599.2019.1683694.

El-Mashaleh, M.A. (2009). Construction subcontractor selection model. Jordan Journal of Civil Engineering, 3(4): 375-383.

El-Sayegh, S. (2008). Risk assessment and allocation in the UAE construction industry. International Journal of Project Management, 26(4): 431-438. http://doi.org/10.1016/j.ijproman.2007.07.004.

Enshassi, A., Mohamed, S. and Abu Mosa, J. (2008). Risk management in building projects in Palestine: Contractors' perspectives. Emirates Journal for Engineering Research, 13(1): 29-44.

Faber, W.E. (1979). Protecting Giant Projects: A Study of Problems and Solutions in the Area of Risk and Insurance. Ipswich, UK: Willis Faber.

Faridi, A. and El-Sayegh, S. (2006). Significant factors causing delay in the UAE construction industry. Construction Management and Economics, 24(11): 1167-1 176. http://doi.org/10.1080/01446190600827033. 
Fernando, C.K., Hosseini, M.R., Zavadskas, E.K., Perera, B.A.K.S. and Rameezdeen, R. (2017). Managing the financial risks affecting construction contractors: Implementing hedging in Sri Lanka. International Journal of Strategic Property Management, 21(2): 212-224. http://doi.org/10.3846/1648715X .2017 .1301592 .

Fisk, E.R. (2003). Construction Project Administration. 7th Ed. New Jersey/Ohio: Prentice Hall.

Ghoddousi, P. and Hosseini, M. (2012). A survey of the factors affecting the productivity of construction projects in Iran. Technological and Economic Development of Economy, 18(1): 99-116. http://doi.org/10.3846/20294913 .2012 .661203 .

Ghosh, S. and Jintanapakanont, J. (2004). Identifying and assessing the critical risk factors in an underground rail project in Thailand: A factor analysis approach. International Journal of Project Management, 22(8): 633-643. http://doi.org/10.1016/j.ijproman.2004.05.004.

Goh, C. and Abdul-Rahman, H. (2013). The identification and management of major risks in the Malaysian construction industry. Journal of Construction in Developing Countries, 18(1): 19-32.

Hair Jr, J.F., Hult, G.T.M., Ringle, C. and Sarstedt, M. (2016). A Primer on Partial Least Squares Structural Equation Modeling (PLS-SEM). Thousand Oaks, CA: Sage Publications.

Hair, J.F., Henseler, M., Ringle, C.M. and Mena, J.A. (2012). An assessment of the use of partial least squares structural equation modeling in marketing research. Journal of the Academy of Marketing Science, 40(3): 414-433. http://doi .org/10.1007/s11747-011-0261-6.

Hair, J.F., Ringle, C.M. and Sarstedt, M. (201 1). PLS-SEM: Indeed a silver bullet. Journal of Marketing Theory and Practice, 2(1): 139-152. http://doi.org/10.2753/ MTP1069-6679190202.

Hair, J.F., Sarstedt, M., Hopkins, L. and Kuppelwieser, V.G. (2014). Partial least squares structural equation modeling (PLS-SEM): An emerging tool in business research. European Business Review, 26(2): 106-121. http://doi.org/10.1108/ EBR-10-2013-0128.

Hertz, D.B. and Thomas, H. (1983). Risk Analysis and Its Applications. New York: John Wiley and Sons Inc.

Hlaing, N.N., Singh, D., Tiong, R.L.K. and Ehrlich, M. (2008). Perceptions of Singapore construction contractors on construction risk identification. Journal of Financial Management of Property and Construction, 13(2): 85-95. http://doi.org/10.1108/13664380810898104.

Husin, S., Abdullah, Riza, M. and Afifuddin, M. (2017). Construction cost impacts related to manpower, material, and equipment factors in contractor firms' perspectives. In Proceedings of the 3rd International Conference on Construction and Building Engineering. New York: AIP Publishing.

Hwang, B., Zhao, X. and Ng, S. (2013). Identifying the critical factors affecting schedule performance of public housing projects. Habitat International, 38: 214-221. http://doi.org/10.1016/j.habitatint.2012.06.008.

labal, S., Choudhry, R., Holschemacher, K., Ali, A. and Tamošaitienè, J. (2015). Risk management in construction projects. Technological and Economic Development of Economy, 21(1): 65-78. http://doi.org/10.3846/20294913 .994582 . 
Jarkas, A.M. and Haupt, T.C. (2015). Major construction risk factors considered by general contractors in Qatar. Journal of Engineering, Design and Technology, 13(1): 165-194. https://doi.org/10.1108/JEDT-03-2014-0012.

Jayasudha, K. and Vidivelli, B. (2016). Analysis of major risks in construction projects. ARPN Journal of Engineering and Applied Sciences, 11 (11): 6943-6950.

Jorion, P. (2009). Financial Risk Manager Handbook. 5th Ed. New Jersey: Wiley.

Joshi, N.N., and Lambert, J.H. (2011). Diversification of infrastructure projects for emergent and unknown non-systematic risks. Journal of Risk Research, 14(6): 717-733. http://doi.org/10.1080/13669877.2011.553733.

Kadan, R. (2016). Developing guidelines for managing subcontractors within the constraints of cost and time. MPhil diss. Kwame Nkrumah University of Science and Technology.

Kartam, N. and Kartam, S. (2001). Risk and its management in the Kuwaiti construction industry: A contractors' perspective. International Journal of Project Management, 19(6): 325-335. http://doi.org/10.1016/S0263-7863(00)00014-4.

Kasapoğlu, E. (2018). Risk management in construction. In Sustainable Buildings: Interaction between a Holistic Conceptual Act and Material Properties. London: IntechOpen, 49-71.

Ke, Y., Wang, S., Chan, A. and Cheung, E. (2011). Understanding the risks in China's PPP projects: Ranking of their probability and consequence. Engineering, Construction and Architectural Management, 18(5): 481-496. http://doi. org/10.1108/09699981111165176.

Kwofie, T.E., Adinyira, E. and Fugar, F. (2016). Modelling the effect of housing design unit contract packaging on mass housing project team communication performance. Journal of Construction in Developing Countries, 21 (1): 35-50. http://doi.org/10.21315/jcdc2016.21.1.3.

Kwofie, T.E., Fugar, F., Adinyira, E. and Ahadzie, D.K. (2014). Identification and classification of the unique features of mass housing projects. Journal of Construction Engineering, 2014: 1-11. http://doi.org/10.1155/2014/927652.

Le-Hoai, L., Lee, Y. and Lee, J. (2008.) Delay and cost overruns in Vietnam large construction projects: A comparison with other selected countries. KSCE Journal of Civil Engineering, 12(6): 367-377. http://doi.org/10.1007/s12205 $-008-0367-7$.

Lester, A. (2007). Project Management, Planning and Control: Managing Engineering, Construction and Manufacturing Projects to PMI, APM and BSI Standards. Burlington, MA: Elsevier.

Lew, Y-L., Hassim, S., Muniandy, R. and Hua, L.T. (2018). Structural equation modelling for subcontracting practice: Malaysia chapter. Engineering, Construction and Architectural Management, 25(7): 835-860. http://doi.org/10.1108/ ECAM-04-2017-0073.

Li, H., Arditi, D. and Wang, Z. (2015). Determinants of transaction costs in construction projects. Journal of Civil Engineering and Management, 21 (5): 548-558. http://doi.org/10.3846/13923730.2014.8979.

Lu, S. and Yan, H. (2013). A comparative study of the measurements of perceived risk among constructors in China. International Journal of Project Management, 37: 307-312. http://doi.org/10.1016/j.jproman.2012.06.001.

Manelel, I. and Muya, M. (2008). Risk identification on community-based construction projects in Zambia. Journal of Engineering, Design and Technology, 6(2): 145161. http://doi.org/10.1108/17260530810891289. 
Mansfield, N.R., Ugwu, O.O. and Doran, T. (1994). Causes of delay and cost overruns in Nigerian construction projects. International Journal of Project Management, 12(4): 254-260. https://doi.org/10.1016/0263-7863(94)90050-7.

Mbachu, J. (2008). Conceptual framework for the assessment of subcontractors' eligibility and performance in the construction industry. Construction Management and Economics, 26(1): 471-484. http://doi.org/10.1080/ 01446190801918730.

Mouchi, G. (2011). The skill sets required or managing complex construction projects. Business Education and Accreditation, 3(1): 89-100.

Mullins, L.J. (2005). Management and Organizational Behavior. Essex, England: Pearson Education Ltd.

Nelson, K.K. and Pritchard, A.C. (2007). Litigation risk and voluntary disclosure: The use of meaningful cautionary language. In 2nd Annual Conference on Empirical Legal Studies Paper. New York: New York University School of Law. http://doi.org/10.2139/ssrn.998590.

Ng, S.T., Skitmore, M. and Chung, W.F. (2003). Ten basic factors to identify suitable subcontractors for construction projects. Paper presented at the CIB TG 23 International Conference. Hong Kong, 26-27 October.

Perera, B., Dhanasinghe, I. and Rameezdeen, R. (2009). Risk management in road construction: The case of Sri Lanka. International Journal of Strategic Property Management, 13(2): 87-102. http://doi.org/10.3846/1648-715X .2009.13.87-102.

Perera, B., Rameezden, R., Chileshe, N. and Hosseini, M. (2014). Enhancing the effectiveness of risk management practices in Sri Lankan road construction projects: A Delphi approach. International Journal of Construction Management, 14(1): 1-19. http://doi.org/10.1080/15623599.2013.875271.

Piasny, J. and Paslawski, J. (2015). Selection of sub-contractors as the quality improvement tool in housing construction. Procedia Engineering, 122: 274281. http://doi.org/10.1016/j.proeng.2015.10.036.

PMI (Project Management Institute) (2013). A Guide to the Project Management Body of Knowledge (PMBOK Guide). 5th Ed. Pennsylvannia: PMI Inc.

Polat, G. (2016). Subcontractor selection using integration of the AHP and PROMETHEE methods. Journal of Civil Engineering Management, 22(8): 1042-1054. http:// doi.org/10.3846/13923730.2014.948910.

Rane, S.B., Potdar, P.R. and Rane, S. (2019). Development of project risk management framework based on industry 4.0 technologies. Benchmarking: An International Journal. http://doi.org/1010.1108/BIJ-03-2019-0123.

Samuel, L. (2009). Subcontract and supply enquiries in the tender process of contractors. Journal of Construction Management and Economic, 27(12): 1220-1221. http://doi.org/1010.1080/01446190903394533.

Sarstedt, M., Hair, J.F., Ringle, C.M., Thiele, K.O. and Gudergan, S.P. (2016). Estimation issues with PLS and CBSEM: Where the bias lies! Journal of Business Research, 10(1): 3998-4010. http://doi.org/1010.1016/j.jbusres.2016.06.007.

Sarstedt, M., Ringle, C.M., Smith, D., Reams, R. and Hair, J.F. (2014). Partial least squares structural equation modeling (PLS-SEM): A useful tool for family business researchers. Journal of Family Business Strategy, 1(1): 105-115. http://doi.org/1010.1016/j.jfbs.2014.01.002. 
Shafii, F., Ali, Z.A. and Othman, M.Z. (2006). Achieving sustainable construction in the developing countries of Southeast Asia. Paper presented at the 6th AsiaPacific Structural Engineering and Construction Conference. Kuala Lumpur, Malaysia, 5-6 September.

Straub, D., Boudreau, M.C. and Gefen, D. (2004). Validation guidelines for IS positivis† research. Communications of the Association for Information Systems, 13(1): 24.

Streiner, D.L. and Norman, G.R. (1989). Health Measurement Scales: A Practical Guide to Their Development and Use. New York: Oxford Medical Publications.

Tadayon, M., Jaafar, M. and Nasri, E. (2012). An assessment of risk identification in large construction projects in Iran. Journal of Construction in Developing Countries, 17(1): 57-69.

Tang, W., Qiang, M., Duffield, C.F., Young, D.M. and Lu, Y. (2007). Risk management in the Chinese construction industry. Journal of Construction Engineering and Management, 133(12): 944-956. http://doi.org/10.1061/(ASCE)0733 -9364(2007) 133:12(944).

Turkey, W. (2011). Risk factors leading to cost overrun in Ethiopian federal road construction projects and its consequences. MSc diss. Addis Ababa University.

Wang, W. (2000). Application of Multi-Objective Genetic Algorithms to Optimize Project Organization. Technical Report. Taiwan: National Science Council.

Wiguna, I. and Scott, S. (2005). Nature of the critical risk factors affecting project performance in Indonesian building contracts. In F. Khosrowshahi (ed.), Proceedings of the 21st Annual ARCOM Conference. London: Association of Researchers in Construction Management (ARCOM), 225-235.

Zavadskas, E.K., Turskis, Z. and Tamošaitiene, J. (2010). Risk assessment of construction projects. Journal of Civil Engineering and Management, 16(1): 33-46. http://doi.org/10.3846/jcem.2010.03.

Zayed, T., Amer, M. and Pan, J. (2008). Assessing risk and uncertainty inherent in Chinese highway projects using AHP. International Journal of Project Management, 26(4): 408-419. http://doi.org/10.1016/j.ijproman.2007.05.012.

Zedan, H. and Martin, S. (1995). Evaluating contractor prequalification data: Selection criteria and project success factors. Journal of Construction Management and Economics, 2(1): 129-147. http://doi.org/10.1080/01446199700000002.

Zou, P., Zhang, G. and Wang, J. (2007). Understanding the key risks in construction projects in China. International Journal of Project Management, 25(6): 601614. http://doi.org/10.1016/j.ojproman.2007.03.001. 